\title{
ПОТОЧНИЙ СТАН ВИЩОЇ ОСВІТИ В УКРӒ̈НІ: ПРОБЛЕМИ, ПРИЧИНИ, ПЕРСПЕКТИВИ
}

\author{
Пропозиції підгрупі № 1 «Аналіз поточного стану системи вищої освіти \\ України» робочої групи з розроблення проєкту Cmpamегії розвитку вищої \\ освіти в Україні на 2021-2031 роки
}

https://doi.org/10.37472/2707-305X-2020-2-2-11-2

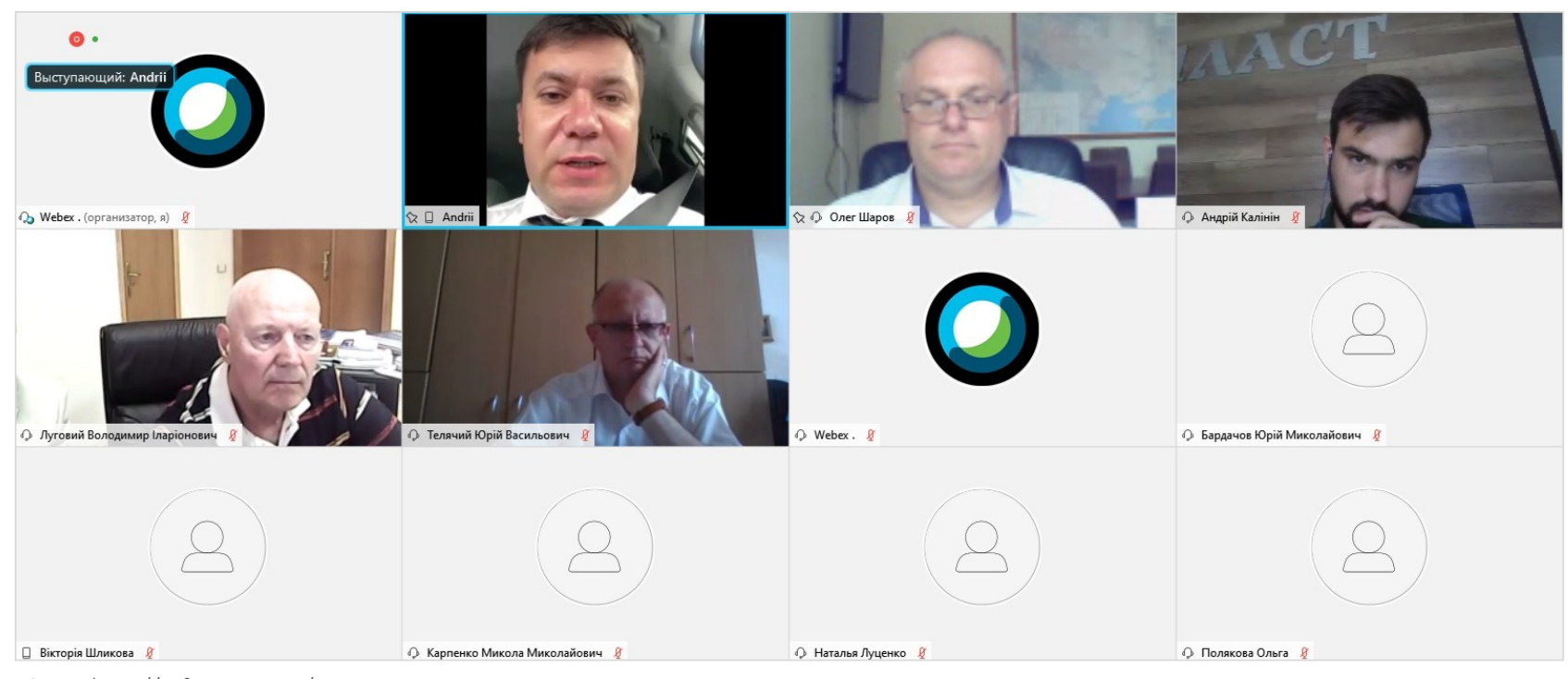

Фото: http://reform.org.ua/

\section{лУгОВИЙ}

\section{Володимир Іларіонович}

доктор педагогічних наук, профресор, дійсний член (академік) НАПН України, перший віцепрезидент Начіональної академії педагогічних наук України, член робочої групи МОН України з розроблення проєкту Cтратегії розвитку вищої освіти в Україні на 2021-2031 роки, м. Київ, Україна

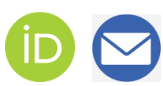

Анотація. 3 урахуванням результатів авторських досліджень національної сфери вищої освіти у 1990-2019 рр. ідентифіковано ключові ї̈ проблеми та причини їх виникнення, що стратегічно важливі для обгрунтування перспектив подальшого розвитку цієї сфери. Аргументовано домінування турбулентного і стихійного характеру змін у вищій освіті впродовж останнього 30-річного періоду, що призвело до неефективності їі мережі, яка не може слугувати надійною основою виходу з кризи та прогресу. 3-помін істотних мережних вад - подрібненість і розпорошеність, ресурсна деконцентрованість, надмірна дубльованість підготовки, профільна неадекватність закладів, іхх дослідницька слабкість. Не створено умов для реалізації дослідницько-інноваційної функції науково-педагогічного персоналу. Не сформовано систему механізмів моніторингу і оцінювання, забезпечення і вдосконалення якості вищої освіти, зокрема рейтингових, відсутні інституційні та предметно-галузеві профілі університетської якості. Це утруднює доцільний та ефективний розподіл великих бюджетних коштів між закладами. Для стратегічного розв'язання комплексу зазначених проблем запропоновано укрупнення закладів, консолідацію і концентрацію відповідних ресурсів.

Ключові слова: стан вищої освіти; проблеми мережі; дослідницько-інноваційна функція викладачів; конкурентоспроможна якість; механізми моніторингу і оцінювання якості; профіль якості вищої освіти; укрупнення закладів; концентрація ресурсів. 
За результатами участі в першому засіданні підгрупи № 1 «Аналіз поточного стану системи вищої освіти України» робочої групи з розроблення проєкту Стратегії розвитку вищої освіти в Україні на 2021-2031 роки (далі - Стратегія), утвореної наказом МОН України від 28 липня 2020 р. № 974, запропоновано врахувати наступне.

1. Система вищої освіти України впродовж 1991-2019 рр. зазнала турбулентних змін, що призвело до її недостатньої конкурентоспроможності. Наприклад, в одному 1994 р. в умовах скорочення ВВП відкрито нових 73 університети, академії, інститути. Навпаки, у 2014 р. припинили існування 48 закладів вищої освіти (ЗВО). 3 того часу кількість 3ВО знову збільшилася і залишається надмірною, а заклади подрібненими (див. рис.). Ще більш слабкими є багаточисельні відокремлені структурні підрозділи закладів. Загалом стан національної вищої освіти не відповідає статусу великої самостійної і самодостатньої країни - України.

2. Нині в Україні за критеріями провідного світового Шанхайського рейтингу відсутні університети світового класу (у групі топ 500) та університети субсвітового класу (кандидати у світовий клас, група 501-1000), а також університети світового і субсвітового класу у 54 предметних галузях за цим рейтингом. У цьому Україну обійшли усі країни-сусіди, крім Молдови. До Шанхайського рейтингу загальної та/або галузевої (предметної) версій у 2020 р. з пострадянських країн входять Білорусь, Грузія, Естонія, Казахстан, Латвія, Литва, Росія.

3. Причиною низької конкурентоспроможності української вищої освіти є недосконалість ії мережі: подрібненість і розпорошеність, ресурсна (кадрова, фінансова, інформаційна, інфраструктурна) деконцентрованість, надмірна дубльованість, профільна неадекватність, дослідницька слабкість. Наприклад, у Києві у 2019 р. прийом на денну бакалаврську підготовку з права здійснювали 37 закладів, у 2020 р. - 36 закладів. У Кіровоградській області усього 8,6 тис. студентів, натомість функціонує 8 3ВО, усі в Кропивницькому, 6 з них готують здобувачів у галузі права.

4. Через велике навчальне навантаження, неконкуретоспроможність заробітної плати, що спонукає до підробітків, застарілість або відсутність дослідницької інфраструктури в українських закладах слабо здійснюється «науково»«педагогічна» функція викладачів. у 3 ВО за

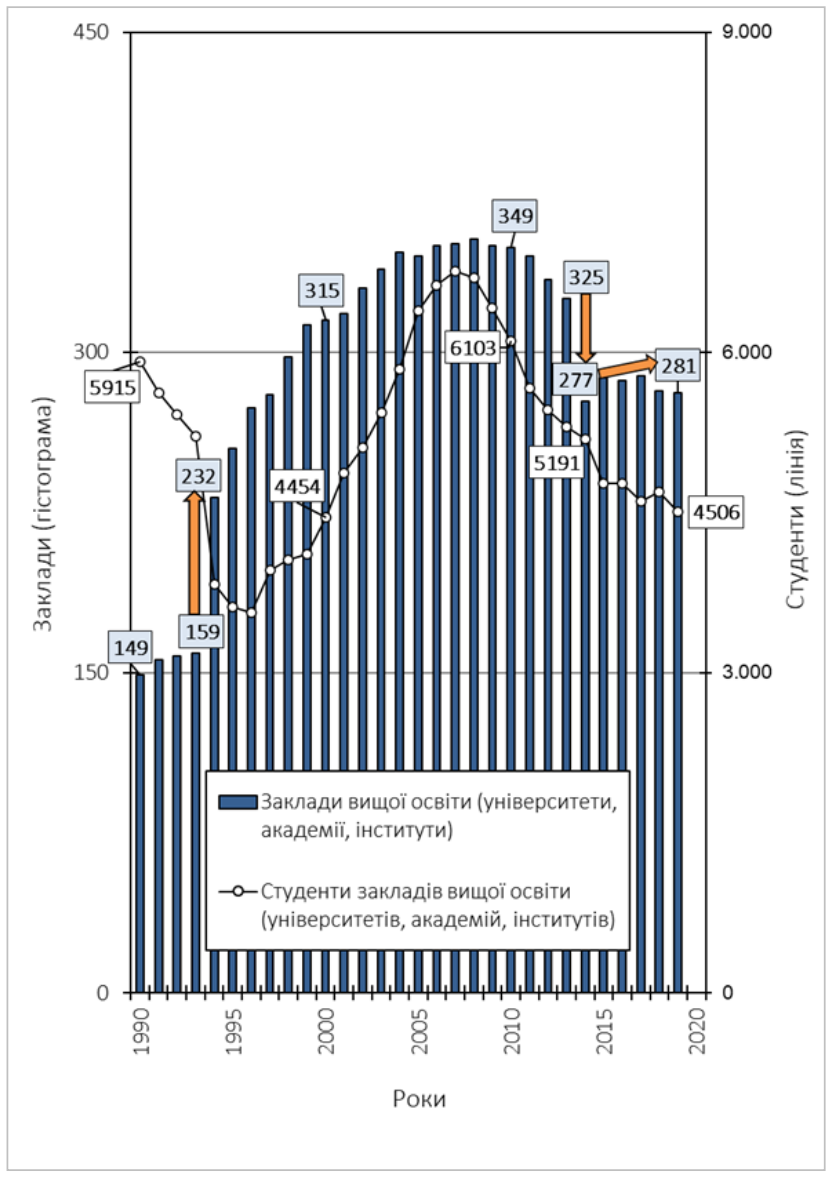

Рис. Кількість закладів вищої освіти і середня чисельність здобувачів в одному закладі в Україні у 1990-2019 рр.

основним місцем роботи зосереджено понад 70 \% наявних в національній економіці кандидатів і докторів наук, які не можуть повною мірою із вище зазначених причин реалізувати свій дослідницько-інноваційний потенціал.

5. Переведенню української вищої освіти в русло цілеспрямованого розвитку стримує нерозвинутість або відсутність механізмів оцінювання якості вищої освіти, відтак визначення за їх допомогою профілю якості вищої освіти як інституційного (у цілому), так і галузевого (за галузями знань). За створенням системи механізмів моніторингу і оцінювання, забезпечення і вдосконалення якості вищої освіти Україна відстає від світової і європейської практики. Країна достеменно не знає університетів-аутсайдерів та університетів-лідерів, перспективних національних центрів університетського розвитку. Українські громадяни, суспільство і економіка потерпають від відсутності національного об'єктивного, валідного та вірогідного рейтингового оцінювання закладів. Зазначене ускладнює ефективне і доцільне спрямування фінансових ресурсів на вищу освіту, обсяг яких у 2019 р. лише з держав- 
ного бюджету досяг 44 млрд грн, 27 млрд грн за загальним і 17 млрд грн за спеціальним фондами. Це більш як у 2,5 рази перевершує загальний обсяг фінансування позауніверситетських наукових досліджень і розробок (близько 17 млрд грн). Для порівняння, у США обсяги фінансування вищої освіти (higher education) та позауніверситетських досліджень і розробок (research \& development) паритетні (приблизно по 0,5 трлн доларів). Дослідницький потенціал університетів у передових країнах (США, Японія, Корея, Китай, Німеччина, Франція, Сполучене Королівство) насамперед реалізується через «дослідницьких професорів» за моделлю «професор і дослідник - одна персона», створенням для цього відповідних умов. Такі умови у світовій практиці (Німеччина, Сполучене Королівство, Фінляндія, Франція, Японія, Китай) передовсім досягаються укрупненням і консолідацією закладів вищої освіти та концентрацією у такий спосіб відповідних ресурсів.

\section{СПИСОК ВИКОРИСТАНИХ ДЖЕРЕЛ}

Виконання критеріїв надання та підтвердження статусу національного закладу вищої освіти : аналітичний звіт. (2019). Київ: Національне агентство із забезпечення якості вищої освіти. https:// naqa.gov.ua/wp-content/uploads/2019/10/A-2019-120191015-3.pdf

Вища освіта в Україні у 2019 рощі : статистична інформація. (2020). Київ: Державна служба статистики України. http://www.ukrstat.gov.ua/

Воробйова, О., Дебич, М., Линьова, І., Луговий, В., Оржель, О., Слюсаренко, О., Таланова, Ж., \& Трима, К. (2018). Аналіз провідного вітчизняного та зарубіжного досвіду щодо оцінювання якості вищої освіти в умовах євроінтеграції (частина I) : аналітичні матеріали (В. Луговий, Ж. Таланова, ред.). Київ: ІВО НАПН України. https://bit.ly/2Ctk3Ei

Воробйова, О., Дебич, М., Луговий, В., Оржель, О., Слюсаренко, О., Таланова, Ж., \& Трима, К. (2019). Аналіз провідного вітчизняного та зарубіжного досвіду щодо оцінювання якості вищої освіти в умовах євроінтеграції (частина II) : аналітичні матеріали. (В. Луговий, Ж. Таланова, ред.). Київ: ІВО НАПН України. https://doi.org/10.31874/978-6177486-28-1-2019

Воробйова, О.П., Гриценко, М.В., Луговий, В.І., Оржель, О.Ю., Слюсаренко, О.М., Ставицький, А.В. Таланова, Ж.В., Ткаченко, В.П., \& Трима, К.А. (2017). Світоглядні пріоритети гуманізації вищоі освіти : монографія (В.І. Луговий, Ж.В. Таланова, ред.). Київ: IBO НАПН України.https://bit.ly/2ZAPRPa

Bcmyn.OCBITA.UA. (2020). https://vstup.osvita.ua/

Державна казначейська служба України. (2020). Річний звіт про виконання Державного бюджету України за 2019 рік. https://www.treasury.gov.ua/ua/filestorage/richnij-zvit-pro-vikonannya-derzhavnogobyudzhetu-ukrayini-za-2019-rik

Закон України. (2014, 1 липня). Про вищу освіmу (1556VII). http://zakon5.rada.gov.ua/laws/show/1556-18
Інформаційна система «Конкурс». (2020). Вступна кампанія 2019 року. http://vstup.info/\#2019

Кабінет Міністрів України. (2017, 22 листопада). Про затвердження Порядку та критеріїв надання закладу вищої освіти статусу національного, підтвердження чи позбавлення цього статусу (912). https://zakon.rada.gov.ua/laws/show/912-2017-п Кабінет Міністрів України. (2018, 14 березня). Про затвердження переліку світових рейтингів університетів для визначення особливої категорії іноземців та осіб без громадянства, які претендують на працевлаштування в Україні (154-р). http://zakon.rada.gov.ua/laws/show/154-2018-p

Кабінет Міністрів України. (2019, 24 грудня). Про розподіл видатків державного бюджету між закладами вищої освіти на основі показників їх освітньої, наукової та міжнародної діяльності (1146). https://zakon.rada.gov.ua/laws/show/11462019-п

Концептуальні засади реформування публічного фінансування та управління закладами вищої освіти. (2019). https://osvita.ua/vnz/reform/69080/

Луговий, В.І., Слюсаренко, О.М., \& Таланова, Ж.В. (2018а). Нові уроки лідерства для України від Шанхайського рейтингу 2018 року. Педагогіка і психологія. Вісник НАПН України, (3), 5-22.

Луговий, В.І., Слюсаренко, О.М., \& Таланова, Ж.В. (2018b). Світовий досвід для створення національного рейтингу закладів вищої освіти. Педагогіка i психологія. Вісник НАПН України, (2), 5-23.

Міністерство освіти і науки України. (2020, 28 липня). Про утворення робочої групи з розроблення проєкту Cтратегії розвитку вищої освіти України на 2021-2031 роки (974). http://reform.org.ua/

Освіта.иа. (2020). Рейтинги ВН3. https://osvita.ua/vnz/ rating/

Президент України. (2020, 3 червня). Про вдосконалення вищої освіти в Україні (210). https:// www.president.gov.ua/documents/2102020-34045

Слюсаренко, О.М. (2015). Розвиток найвищого університетського потенціалу в умовах глобалізації : монографія. Київ: Пріоритети. https:// lib.iitta.gov.ua/10225/

Таланова, Ж.В. (2010). Докторська підготовка у світі ma Україні : монографія. Київ: Міленіум. https:// bit.ly/30Yv75J

Lugovyi, V., Orzhel, O., Slyusarenko, O., \& Talanova, Zh. (2018). Education and research duality - the determining characteristic of higher education. Education: Modern Discourses, (1), 71-88. https:// doi.org/10.32405/2617-3107-2018-1-8

Lugovyi, V., Slyusarenko, O. \& Talanova, Zh. (2019). University rating \& development: challenges and opportunities for Ukraine. Education: Modern Discourses, (2), 60-77. https://doi.org/10.32405/26173107-2019-1-8

ShanghaiRanking Consultancy. (2019, August 15). ShanghaiRanking's Academic Ranking of World Universities 2019 Press Release. http:// www.shanghairanking.com/Academic-Ranking-ofWorld-Universities-2019-Press-Release.html

ShanghaiRanking Consultancy. (2020, June 29). ShanghaiRanking's Global Ranking of Academic Subjects 2020 Press Release. http://www.shanghairanking.com/ ShanghaiRankings-Global-Ranking-of-AcademicSubjects-2020-Press-Release.html 
THE CURRENT STATE OF HIGHER EDUCATION IN UKRAINE: PROBLEMS, CAUSES AND PERSPECTIVES

Proposals for the Subgroup No 1 "Analysis of the Current State of Higher Education System in Ukraine" of the Working Group on Designing the Draft Strategy for the Development of Higher Education in Ukraine for 2021-2023

\section{Volodymyr Lugovyi}

DSc in Education, Professor, Full Member (Academician) of NAES of Ukraine, First Vice-President, National Academy of Educational Sciences of Ukraine, Member of the Ministry of Education and Science of Ukraine Working Group on Designing the Draft Strategy for the Development of Higher Education in Ukraine for 2021-2023, Kyiv, Ukraine

Abstract. The key problems and their causes, which are strategically important for grounding the perspectives for further development of higher education, are identified taking into account the author's research results of the Ukrainian higher education sphere functioning in 1999-2019. The dominance of turbulent and spontaneous character of changes in higher education during the last 30-year period is argued. This caused the inefficiency of its network, which cannot serve as a reliable basis for overcoming the crisis and progress. Among the significant network defects are: fragmentation and dispersion, resources deconcentration, excessive duplication of training, profile inadequacy of institutions, their research weakness. The conditions for academic staff research and innovation function realisation are not assured. The system of mechanisms for higher education quality monitoring and evaluation, assurance and improvement is not formed, in particular ranking, there are no institutional and subject profiles of university quality. This complicates expedient and effective distribution of the large budget funds between institutions. The institutions' consolidation and resource concentration are proposed for strategic solving of the mentioned problems.

Keywords: the state of higher education; network's problems; academic staff research and innovation function; competitive quality; mechanisms of quality monitoring and evaluation; higher education quality profile; institutions' consolidation; resource concentration. 